\title{
SLUM DISTRIBUTION: CASE STUDY OF DEHRADUN CITY
}

KEY WORDS: Slum, Water Supply, Solid Waste Management, Drainage, Sanitation

\section{Dr. Doreshor} Khwairakpam

Associate Professor,

Ar. Kapil

Balmiki*

\section{Ar. Eti Agarwal}

\author{
Master Students M Plan *Corresponding Author
}

Research Scholar, Amity School of Architecture and Planning, Amity University, Haryana, India

Slum is one of the characters in our urban system. They are more vulnerable section of our society in all kinds of disaster flood, heat wave, etc. The slum population is already crossed 65.5 million (22.5 percent) that distributed in 2613 towns/cities in India as per census, 201 1. In this context, slum distribution scenario has been conducted in Dehradun city, India. It is the capital city of Uttarakhand state located in the foothill of Himalaya with a population of approximately 578420 (census 2011). The aim of this study for slum distribution in wards wise within Dehradun city to draw a lesson to understand the scenario of services facilities in the selected wards - ward number 14,20,35 and 36. The objectives are(1). to study the slum distribution in Dehradun city through mapping, (2) to study the slum households shared in ward wise in the administrative boundary of Dehradun city and, (3) to study the comparative scenario of services sectors such as water supply, drainage, and solid waste management. The methodology has adopted based on the secondary data available to public domain and field investigation and observation.

\section{INTRODUCTION}

Slum is defined as "A slum household as a group of individuals living under the same roof in an urban area who lack of one or more of the following: 1. Durable housing of a permanent nature that protect against extreme climate conditions. 2 . Sufficient living space which means not more than three people sharing the same room. 3. Easy access to safe water in sufficient amount at an affordable price. 4 Access to adequate sanitation in the form of a private or public toilet shared by a reasonable number of people. 5. Security of tenure that prevent force evictions (UN., 2001). In Indian context, "A Slum is a compact settlement with a collection of poorly build tenements, mostly of temporary nature, crowded together usually with inadequate sanitary and drinking water facilities in unhygienic condition (NSSO., 2002). As per the census 201 1, slum is existing in all state and union territories accept Manipur state. It is a common phenomenon and will continue to grow in future. The main causes of slum formation are - (1) "Location Choice Factors": slum has been form based on the socio-culture and economic and physical factors, (2) "Rural to Urban Migration": moving to urban area to get better job opportunities, (3) "Urban Poor Governance" Due to the poor governance has heading to form slum as demand of housing and services facilities are not able to meet the demand, (4) "Ill design Policies" -it is very close to the design the policies and programme to address the slum issue and inappropriate policies would not be able to feed the demand and services for slum dwellers (Ron M., Adrew C., etl., 2016). So many challenges are being faced by government of India at state and Urban Local Bodies (ULBs) level to eradicate the slum across the country.There are series of schemes and programms such as JnNURM, National Slum Development Program (NSDP), Integrated Housing and Slum Development Programmes (IHSDP) etc to address the slum issues (MoUD, 2011). So, this paper is to bring the slum situation of Dehradun city as case study to digest the current situation.

\section{Case Study of Dehradun City}

Dehradun city is surround by hills in north and south and laying down along the river of Ganga and Yamuna respectively (Riyan H., and Sana J., 2019). Total population of city was 578420 as per census 2011 with an area of $196.5 \mathrm{~km}^{2}$ approximately. This city is growing at faster in the last few decades and simultaneously increased the number of slum population in this city. As a result, inadequate infrastructure is one challenge in the city particularly for slum population. The slum pocket has been spatial distributed in every corner of the city and identified the slum pockets in all wards (Fig. 1) with different size in terms of population and area. The condition in these slum pockets is very poor in terms of services delivery and unhygienic, polluted environment. Even in the other services sectors such as solid waste management and drainage are bad in condition due to lack of maintenance.

Fig. 1: Map of Dehradun City with Distribution of Slum Population (2011)

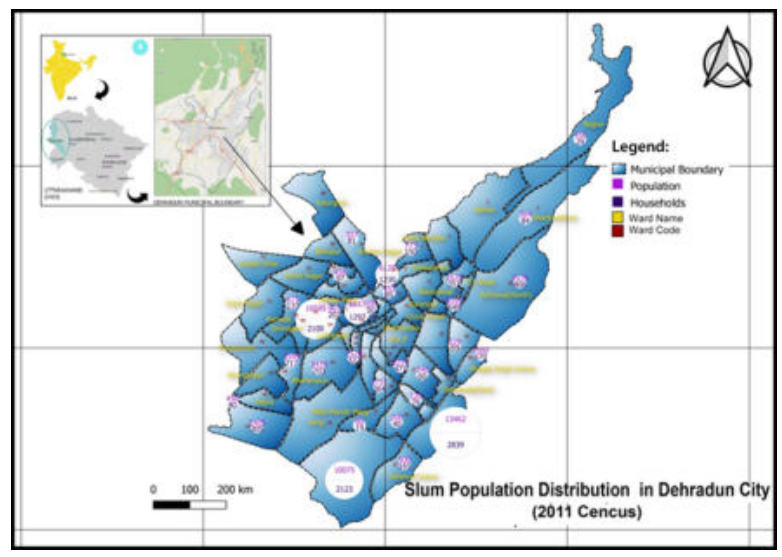

Source:

\section{Distribution Of Slum Households In Dehradun City In WardWise}

There are 24 wards namely Raipur (ward No. 1), Sharstradhara (ward No. 2), Jakhan (ward No. 3), Hathibadkola (ward No. 4), Araya Nagar (Ward No. 5), Dobhalwala (Ward No. 6), Vijay Coloney (Ward No. 7), Kishan Nagar (Ward No. 8), D L Road (Ward No. 9), Respana (Ward No. 10), Karanpur (Ward No. 11), Bakralwala (Ward No. 12), Ghantaghar (Ward No. 15), M.K.P (Ward No. 17), KalikaMandir Marg (Ward No. 18), Shivaji Marg (Ward No. 21), Dhamawala (Ward No. 23), JhandaMohala (Ward No. 24), Dalanwala(Ward No. 25), Dalanwala(East) (Ward No. 26), Nehru Coloney (Ward No. 33), Rest Camp 
(Ward No. 39), Retha Mandi (Ward No. 40), Kargi (Ward No. 42), Niranjanpur (Ward No. 45), Indrapuram (Ward No. 48), Dronpuri (Ward No. 49), Indranagr (Ward No. 51), BasantVihar (Ward No. 52), Mohit Nagar (Ward No. 53), Patel Nagar (West) (Ward No. 54), Yamuna Coloney (Ward No. 56), GovindGadh (Ward No. 57), Balupur (Ward No. 59), and Kailagrath (ward No. 60) do not have slum population out of 60 wards in the Dehradun city. The distribution of slum households shared maximum in ward Nos. $31,20,14$ and 35 and less as comparison to the other wards (Fig.2) The overall distribution of slum population in different size and different distribution in terms of the total population in wards wise respective. The Indira Nagar Colony (ward No. 14), Khurbura (ward No. 20), Gandhi Gram (ward No. 35), Deepnagar (ward No. 55) and Rajivenagar (ward No.39) are having slum population ranging from 1000 to 2839 population. The rest wards are having less than 1000 population. The percentage of slum population in wards wise is highest in ward No.55, 20,31, and 14 and lowest is in ward No. 37 (Fig. 1).

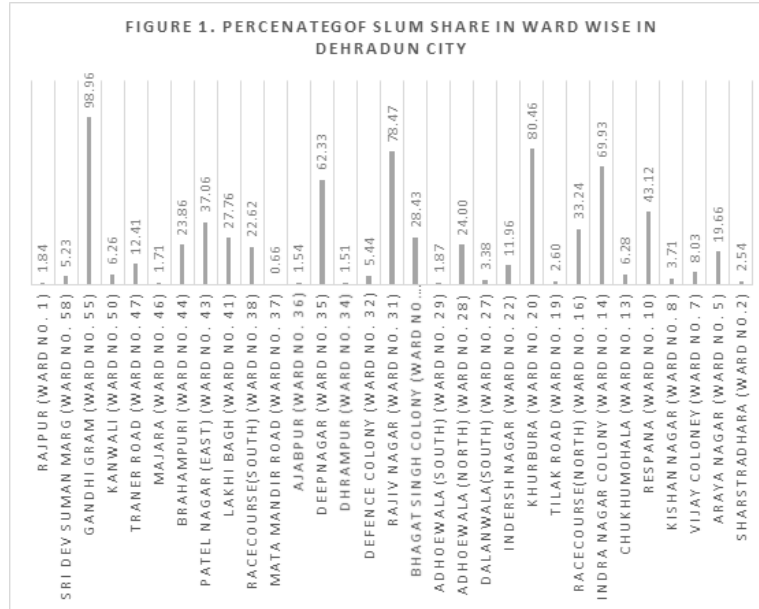

Figure 2. No. of Households in Wardwise in Dehradun City

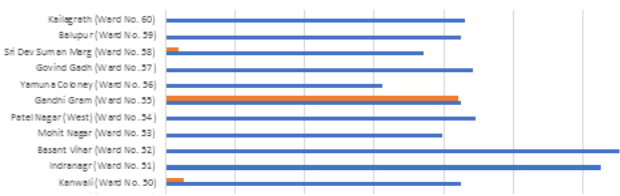

Table 1. Comparative Scenario of Matrix in selected wards of Dehradun City

\begin{tabular}{|c|c|c|c|c|c|c|c|c|c|c|c|c|}
\hline \multirow[t]{3}{*}{ Indicator } & \multicolumn{3}{|c|}{ Ward No. 14} & \multicolumn{3}{|c|}{ Ward No. 20} & \multicolumn{3}{|c|}{ Ward No. 35} & \multicolumn{3}{|c|}{ Ward No. 36} \\
\hline & \multicolumn{12}{|c|}{ Service Sector } \\
\hline & \begin{tabular}{|l|} 
Water \\
Supply
\end{tabular} & Drainage & $\begin{array}{c}\text { Solid } \\
\text { Waste } \\
\text { Manage } \\
\text { ment }\end{array}$ & $\begin{array}{l}\text { Water } \\
\text { Supply }\end{array}$ & Drainage & $\begin{array}{c}\text { Solid } \\
\text { Waste } \\
\text { Manage } \\
\text { ment }\end{array}$ & $\begin{array}{l}\text { Water } \\
\text { Supply }\end{array}$ & Drainage & $\begin{array}{c}\text { Solid Waste } \\
\text { Manageme } \\
\text { nt }\end{array}$ & $\begin{array}{l}\text { Water } \\
\text { Supply }\end{array}$ & Drainage & $\begin{array}{c}\text { Solid } \\
\text { Waste } \\
\text { Manage } \\
\text { ment }\end{array}$ \\
\hline $\begin{array}{c}\text { Service } \\
\text { Performance }\end{array}$ & $40 \%$ & $24 \%$ & $78 \%$ & $77 \%$ & $44 \%$ & $25 \%$ & $80 \%$ & $38 \%$ & $18 \%$ & $55 \%$ & $80 \%$ & $25 \%$ \\
\hline Color Code & \multicolumn{2}{|c|}{ Poor } & & & \multicolumn{2}{|c|}{ Average } & \multicolumn{4}{|c|}{ Good } & \multirow{2}{*}{\multicolumn{2}{|c|}{$76-100 \%$}} \\
\hline $\begin{array}{c}\text { HHs } \\
\text { Responded } \\
\text { in } \%\end{array}$ & & Poor & $0-3$ & & Aver & rage & $36-$ & $75 \%$ & Good & & & \\
\hline
\end{tabular}

Source: Filed Survey, 2020

Figure 3: Photographs Showing Scenario of Selected Ward Numbers

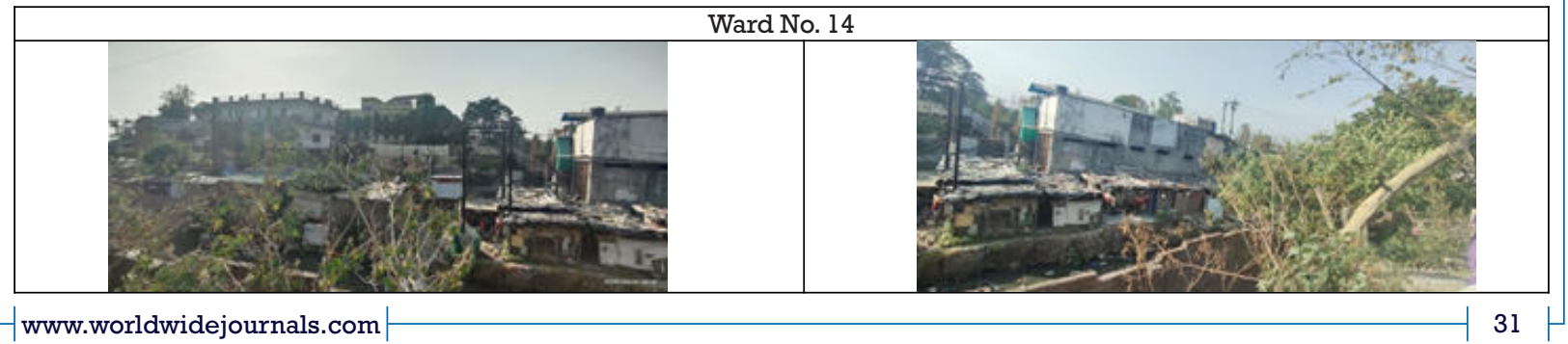




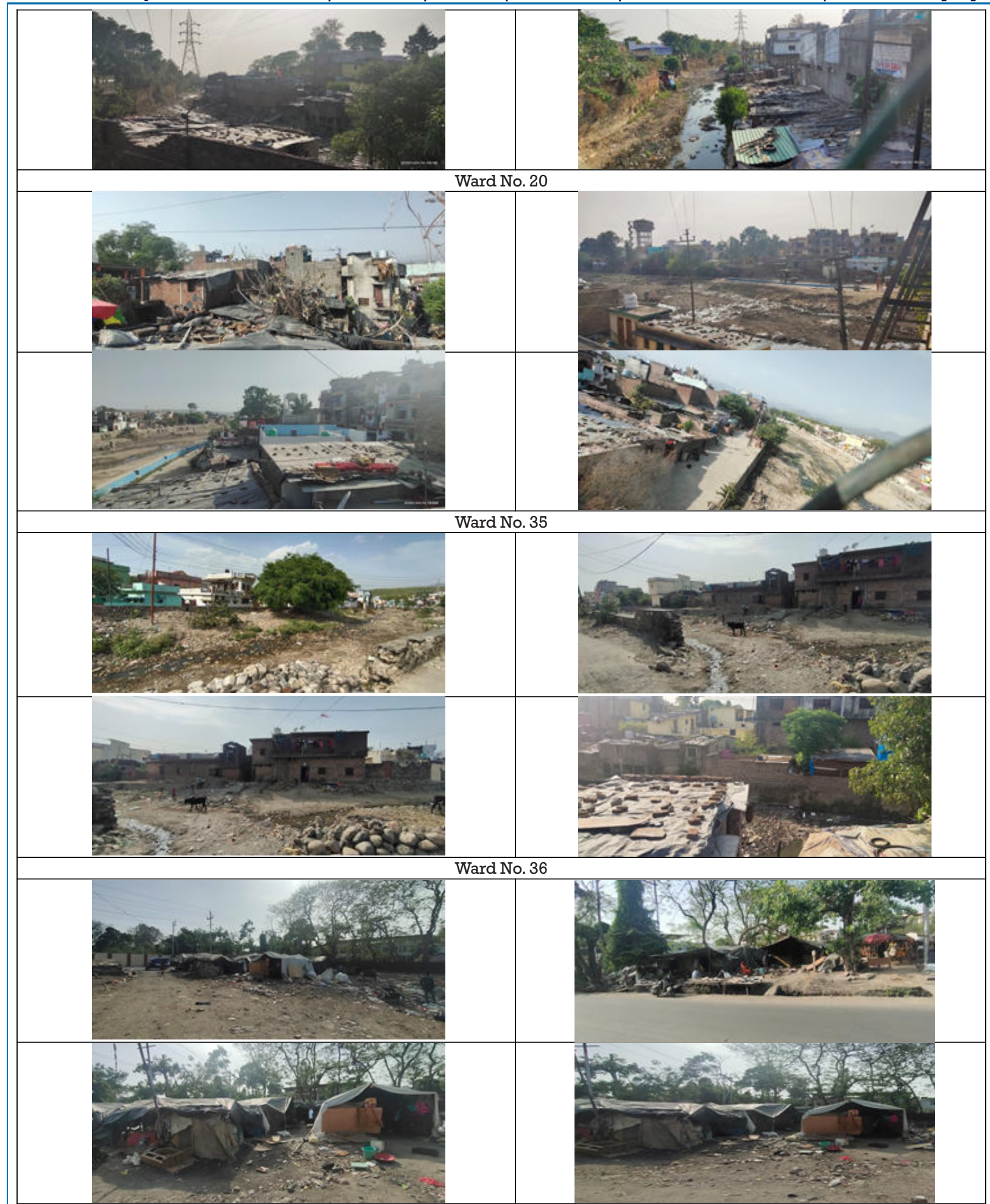

\section{Source: Photographs Credited by Kapil, 2021}

\section{Conclusion and Recommendation}

Slum pockets is being distributed at maximum wards and facing issues particularly for solid waste management sector. Hence it should encourage to the Urban Local Bodies (ULBs) for proper collection of solid waste and transport to the dumping site. And involvement of community (slum dweller) is mandatory to improve the solid waste management in selected studies areas. Other sectors of infrastructure services such as water supply and drainage are needed to plan properly to improve the effective efficient of services delivery as per the infrastructure service benchmarks documented by government of India. It would be preliminary study for further research to bring the innovative ideas in order to plan for improvement of the identified slum pockets in Dehradun city.

\section{REFERENCE S}

1. MoHUA., (2011): Schemes and Programmes., Ministry of Housing and Urban Affairs, Delhi, Government of India

2. NSSO.,(2002): NSSO survey data 2002, National Sample Survey Organization, Ministry of Statistics, Delhi

3. Office of Registrar General., (2011), Slum Population, Government of India, Office of Registrar,Delhi

4. Riyan Habeeb and Sana Javaid.,(2019): Social Inclusion of Marginal in the Great Climate Change Debate: Case of Slums in Dehradun, India, Sage

5. Ron Mahabir, Andrew Croks, Aries Croitoru, Peggy Agouris., (2016): The Study of Slums as physical Constructs: Challenges and Emerging Research 
PARIPEX - INDIAN JOURNAL OF RESEARCH | Volume - 10 | Issue - 10 | October - 2021 | PRINT ISSN No. 2250 - 1991 | DOI : $10.36106 /$ paripex Opportunities, Regional Studies, Regional ScienceVol.3(1)
United Nation., (2001): State of the World Cities2006-07, United Nation,
Habited 